\title{
A Review of Studies on Public Private Partnership Projects in the Construction Industry
}

\author{
LiYaning Tang ${ }^{1}$, Qiping Shen*, Eddie W. L. Cheng ${ }^{2}$ \\ ${ }^{1}$ Research student, Department of Building and Real Estate, Hung Hum, \\ Kowloon, Hong Kong. Tel.: +852 27664308; Fax: +852 27645131. E-mail \\ address:07900729r@polyu.edu.hk.
}

* Corresponding author. Chair Professor, Department of Building and Real Estate, Hung Hum, Kowloon, Hong Kong. Tel.: +852 27665817; fax: +852

27645131. E-mail address: bsqpshen@polyu.edu.hk

${ }^{2}$ Senior Lecturer, School of Commerce and Management, Southern Cross University. E-mail address: eddie.cheng@scu.edu.au

\section{Abstract}

Public Private Partnership (PPP) in construction is gaining in popularity. Although papers published in major journals have documented real cases of PPP projects, there appears to be a lack of systematically summarizing what they have already provided. Consequently, this paper reviewed PPP studies published in the six top journals in the 
construction field. The objectives are to compare and contrast the findings of the studies so as to provide insights for directing further PPP research and improving the existing practices of PPP projects. To achieve the review objectives, studies were first classified as either empirical or non-empirical. Empirical studies were further grouped under three themes: risks, relationships, and financing. Non-empirical studies were grouped under five themes: financing, project success factors, risks, and concession period. Suggestions for further research are risks, financing, contractual agreements, development of PPP models, concession periods, and strategies in choosing the right type of PPP.

Keywords: Public Private Partnerships, PPP, review, partnering, partnership, construction management

\section{Introduction}

Public private partnership (PPP) projects have caught researchers' attention since this kind of project was introduced in the construction industry. Many researchers have attempted to improve the operation of PPP projects by identifying key aspects of these projects [e.g. Erridge and Greer, 2002; Grimsey and Lewis, 2002; Li et al., 2005b]. Though the PPP approach was widely implemented in the late 1990s, private investment in public infrastructure can be traced back to the 18th century in European countries. A notable example is the concession contract that supplied drinking water 
to Paris. In the 19th century, further similar cases were added from not only the European community (e.g., the Suez Canal and Trans-Siberian Railway, as well as canals, turnpikes, and railroads in Europe) but also their American and Asian counterparts (e.g., United States, China, and Japan) (Kumaraswamy and Morris, 2002).

Since 1997, the PPP approach has been heavily utilized in England (Winch, 2000). Specifically, private companies have so far been involved in facilities development, including designing, financing, construction, ownership, and/or operation of a public sector utility or service (Akintoye et al., 2003). In China, on the other hand, it is foreign firms or international financial institutions rather than domestic institutions that have been involved in PPP projects (Luo et al, 2001). For example, the most successful PPP project in China perhaps is Laibin B power station in Guangxi in 1997.

In fact, there are many forms of PPP, which include the outright privatization of previously state-owned industries (Ng, 2000) and contracting out of services (Efficiency Unit, 2005a). The latter includes services to be performed by private firms, such as refuse collection and cleaning and the use of private finance in the provision of social infrastructure ( $\mathrm{Li}$ and Akintoye, 2003; Sindane, 2000; Tanninen-Ahonen, 2000). In addition to lessons learned from case studies (James et al., 2005), researchers have suggested the advantages of various aspects of PPPs, which include: 
- Enhanced partnership between the public sector and the private sector (e.g. Erridge and Greer, 2002;Ysa, 2007; Zhang and Kunaraswamy, 2001a; Zhang et al., 2002; Zhang, 2004a; Zhang, 2004b),

- Better risk management (e.g. Grimsey and Lewis, 2002; Li et al., 2005a; Shen et al., 2006),

- Clearer government policies (e.g. Ball and Maginn, 2005; Hart, 2003),

- Revealed critical success factors (e.g. Li et al., 2005b),

- Improved maturation of contract (e.g. Ho, 2006; Tranfield et al., 2005), and

- More appropriate financial analysis (e.g. Akintoye et al., 2003; Norwood and Mansfield, 1999; Huang and Chou, 2006; Saunders, 1998).

Despite the fact that studies focused on PPP in construction have been increasing, to date there appears to be a lack of attention paid to the need for summarizing what has already been presented in the literature. In addition, a critical review of the existing literature may improve our understanding of the PPP's advantages and disadvantages. As Li et al. (2000) suggested, "rather than arguing for a particular viewpoint, it would be more beneficial to investigate systematically what we do know and how we can proceed to learn more”. Therefore, a systematic review of relevant PPP studies is undertaken in this paper. In particular, two research objectives have been derived: 
(1) To compare and contrast the findings of the studies by use of a structure set for this paper. This structure is built up by empirical and nonempirical studies.

(2) To provide insights for directing further PPP research. By conducting more research, the existing practices of PPPs can be improved.

The paper starts with a description of the background of the PPP, including its definitions and various forms. The review methodology is then described, including a classification system made for categorizing the retrieved studies. The findings section presents the comparison of results, followed by the discussion section, in which suggestions for further investigation will be given. The final section concludes and summarizes the present research.

\section{Background of PPP}

\subsection{Definitions of PPP}

Sagalyn (2007) contended that existing Public-Private (PP) projects have three generations. In the first generation, mistakes easily emerged due to lack of experience by public and private partners and their consultants. In the second generation, large development companies developed specialized PP urban development projects, often by employing planners who managed PP projects for public entities or led PP corporations. As a result of social development, the third generation has emerged, 
which are PP projects initiated by developers seeking private-sector involvement. The number of PP projects is expanding in the third generation and it is anticipated that they will be used more widely in public service, city reconstruction, and so forth.

The idea of allowing private firms to finance projects of public sector infrastructure results in the emergence of PPPs (Li and Akintoye, 2003; The World Bank, 1992) However, due to many forms of PPP projects and situations in different countries, PPP has various definitions. In the UK, the United Nations Development Programme (2007), when planning PPPs for the Urban Environment, stated that the definition of the PPP should be broad such that even the informal dialogues between government officials and local community-based organizations, which are perceived to be essential to successful PPPs, should be included. In the US, the National Council for Public Private Partnership defines a PPP as a “contractual arrangement between a public sector agency and a for-profit private sector developer, whereby resources and risks are shared for the purpose of delivery of a public service or development of public infrastructure” (Li and Akintoye, 2003). In Canada, the Council for Public Private Partnerships (2007) defines a PPP as a "cooperative venture between the public and private sectors, built on the expertise of each partner, which best meets clearly defined public needs through the appropriate allocation of resources, risks and rewards”.

In Hong Kong, Efficiency Unit (EU) has developed another definition. The EU was set up as a unit of the Office of the Chief Secretary for Administration in Hong Kong in 1992. The vision and mission of the Unit are to provide bureaus and 
departments with high quality management consultancy services and to advance the delivery of world-class public services to the people of Hong Kong (EU, 2005b). The EU (2005a) created a new focus on Private Sector Involvement (PSI) to "assist the government in meeting its priorities, building on the clear recognition that public funds are limited”. As shown in Fig. 1, PSI has two forms: Outsourcing and Public private partnerships (PPPs). It introduced the concept of PPP for the maintenance of infrastructure facilities in Hong Kong, and defines a PPP as “arrangements where the public and private sectors both bring their complementary skills to a project, with varying levels of involvement and responsibility, for the purpose of providing public services or projects”. The Unit describes six forms of PPPs as shown below:

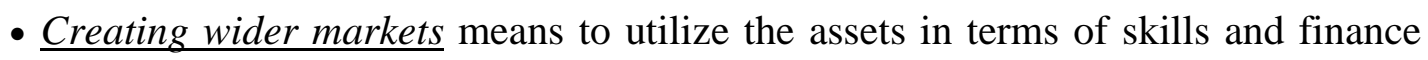
from both the public and private sectors.

- Private Finance Initiatives (PFIs) involve the public sector purchasing quality services while the private sector maintains or constructs the necessary infrastructure. The private sector supplies designs, builds, finances and covers the costs through charges on the users of the asset.

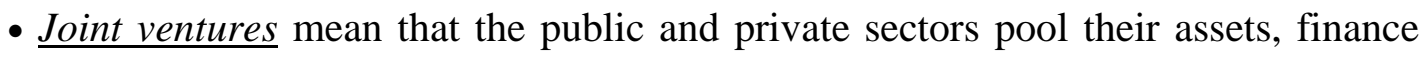
and expertise under joint management. Under this type, the private sector participates more in management. 
- Partnerships companies introduce private sector ownership into state-owned businesses through legislation, regulation, partnership agreements, or retention of a special government share.

- Partnership investments ensure that the public sector shares in the return generated by investments made by private sector parties.

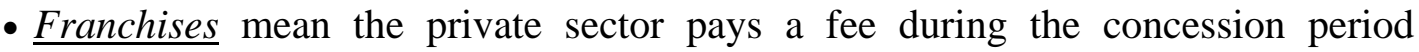
awarded by the government for the revenue (or a share of the revenue) that the service generates.

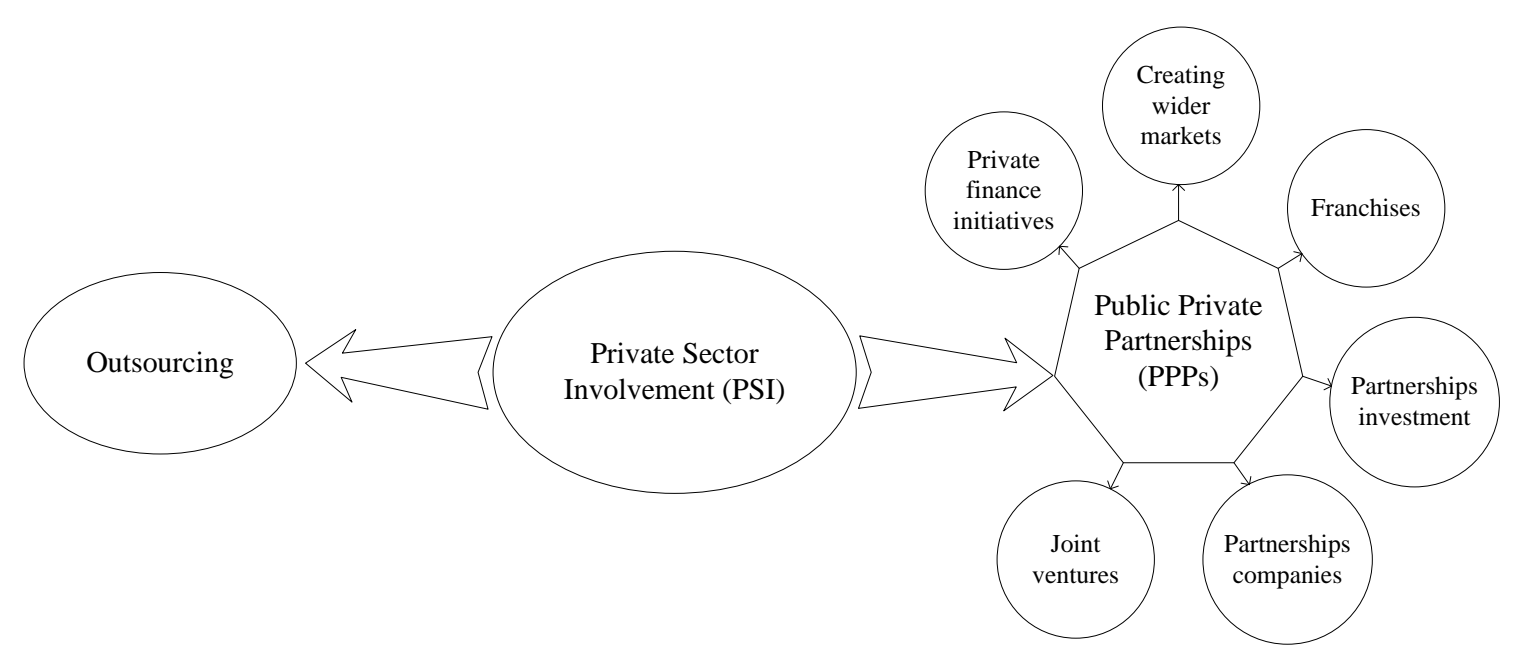

Fig.1. Types of private sector involvement (PSI).

Other than the above forms, Build-Operate-Transfer (BOT) can be regarded as another form of PPP. In a BOT project, the private sector 'builds' the project, 'operates' it for a concession period, and, at the end of the period, 'transfers' it to the client without consideration. 


\subsection{Advantages and disadvantages of PPP}

One of the main advantages of the PPP approach is that it can save resources in many ways. The government can concentrate on its core competencies, and does not need to rely on its own resources for unfamiliar projects (Cumming, 2007). Because of the participation of the private sector, government assets, data and intellectual property can also be utilized more productively, which leads to substantial improvement in the quality of public facilities and services (Edkins and Smyth, 2006). On the other hand, by proper use of the private sector's skills, experience, technology and innovation, public services can be delivered more satisfactorily. A futher advantage is that the public and private sectors can share risks at different stages (Shen et al., 2006). As the private sector brings commercial disciplines into public projects, the risk of cost overruns and project delays can be drastically reduced (Li and Akintoye, 2003; Ho, 2006). To finish the design, build, and operation stages with PPP, the private sector can help to make a leaner civil service structure with a more efficient hierarchy of responsibility for services delivery (EU, 2005a).

Other than the advantages for saving resources and more efficient use of them, the economic aspect can be improved by using the PPP approach. For example, it has been showed that PPP leads to the reduction of lifecycle costs ( $\mathrm{Li}$ and Akintoye, 2003), since these projects spread government capital investment over the life of a project. This guarantees the expected rate of return for governmental investment. 
Although PPP is perceived as a way of creating public infrastructure at little or no cost to the public purse, it is still the notion that "there is no free lunch" is true (Kumaraswamy and Zhang, 2001). Kumaraswamy and Zhang (2001) presented several cases of BOT ventures that had run into problems due to cost overruns, unrealistic price and income projections, and legal disputes between private operators and the government. In virtually all of these cases, the government and the general public, but not the private operators, have ultimately shouldered the cost of failure. Their research led us to focus on the point of view from the public sector about the failure of PPP performance.

Practitioners have indicated that political obstacles stand in the way of using PPPs (Algarni et al., 2007). This view is not surprising since PPP projects always need special legislation. In most circumstances, the municipal or state legislature has to discuss this issue at length before legislation is enacted to regulate the use of PPP. Also, some government agencies may exhibit resistance to change in the context of adopting a new delivery/financing approach. The PPP method of project development may not be well understood and sometimes may not be well received by the government agencies that handle it. 


\section{Research methodology}

In this review, papers relevant to PPP published in the following six leading construction management journals were used: Construction Management and Economics (CME), the ASCE Journal of Construction Engineering and Management (JCEM), Engineering Construction and Architectural Management (ECAM), Journal of Management in Engineering (JME), International Journal of Project Management (IJPM) and Building Research \& Information (BRI).

The selection of these journals was based on Chau's (1997) ranking of journals related to the construction industry. Although Chau's paper was published a decade ago, it was adopted because there appears to be no further updated ranking of construction management journals. The six journals are regarded as the top tier journals in the field. PPP papers published in these journals from 1998 to 2007 were reviewed. The rationale behind this is that mainstream PPP studies have mostly emerged since 1998.

Additionally, the authors of this paper followed the method of Al-Sharif and Kaka (2004) to employ a systematic search to identify papers with the following phrases in subjects, titles, keywords, or abstracts: Public Private Partnership, Private Finance Initiative, Build-Operate-Transfer, Build-Operate-Own, and Joint Ventures. 
Table 1. Number of articles which are related to PPP studies in the selected journals from 1998-2007

\begin{tabular}{lc}
\hline Journal title & Number of papers \\
\hline Journal of Construction Engineering and Management & 35 \\
International Journal of Project Management & 25 \\
Construction Management and Economics & 23 \\
Engineering, Construction and Architectural Management & 14 \\
Journal of Management in Engineering & 6 \\
Building Research and Information & 4 \\
\hline
\end{tabular}

It is important to express here that this paper presents a review of PPP research and is not directly concerned with practical aspects of PPP. The search procedure for papers related to PPP research involves the following three steps:

1. The titles, keywords, and abstracts were scanned with the related keywords. The authors scaled down our search by focusing on the papers published from 1998 to 2007.

2. A brief review of the abstract of the papers was conducted to filter out less related or unrelated papers.

3. After filtering, 107 articles with relevant contents regarding PPP in construction were selected for further analysis.

Table 1 exhibits the number of papers published in the target journals during the period from 1998 to 2007. Over this period, JCEM has published the largest number of PPP papers (= 35), followed by IJPM (= 25), CME (= 23), ECAM (= 14), JME (= 
6), and BRI (=4). This simple number count already indicates that the subject of PPP has already drawn researchers' attention in construction.

To further investigate if the topic is increasing in its popularity, the authors plotted a graph of year (from 1998 to 2007) versus number of PPP papers published in the target journals. As shown in Fig. 2, there is a growing research interest in PPP in construction. Since there has been an increase in PPP papers published in the past few years, it is an appropriate time to produce a systematic review of the existing literature.

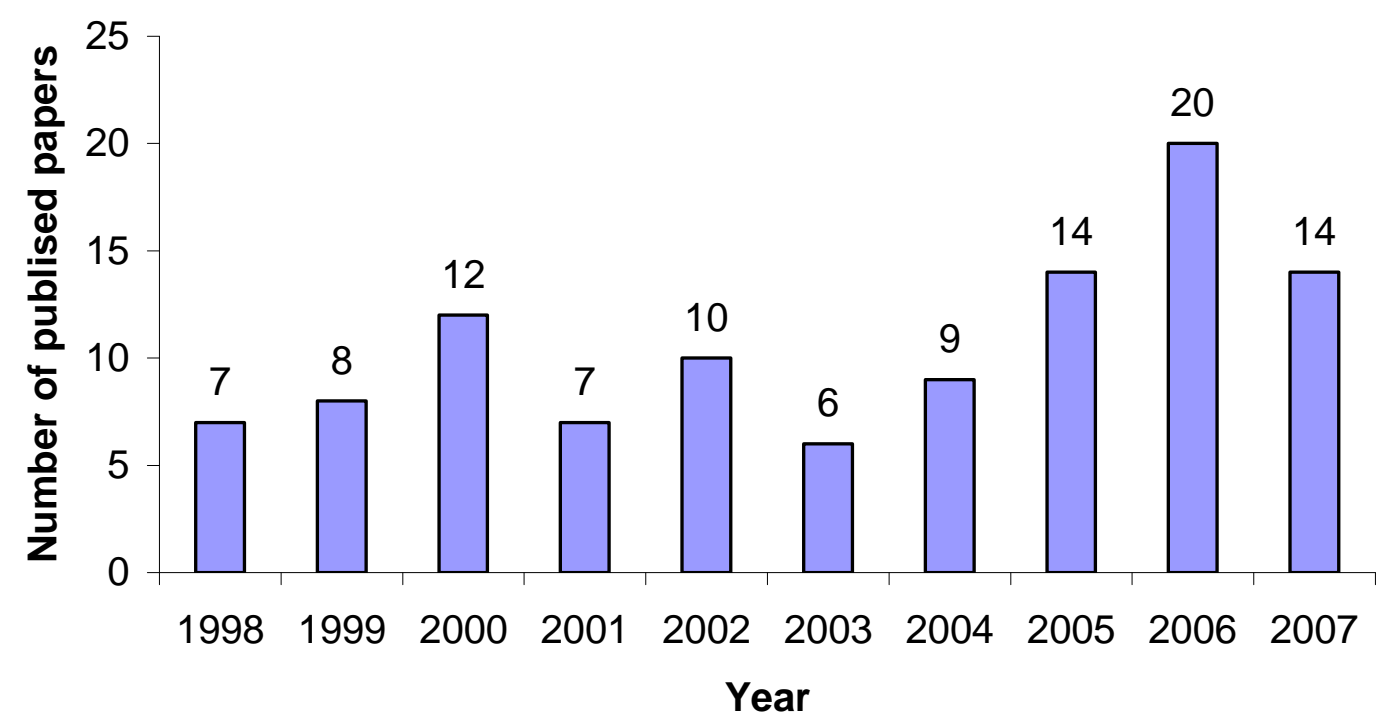

Fig.2. Number of relevant papers published yearly in the selected journals from 1998 to 2007.

The authors of this paper further classified the papers of interest under the methodologies they used. Fig.3 indicates that case study has been mostly used (=57), because it is easier for scholars to draw some implications from real cases than from 
other research methods. Additionally, survey and literature review ranked second and third with 43 and 34 papers respectively, followed by interview (=19). There are also two papers using workshops to get opinions from academic scholars and industry practitioners.

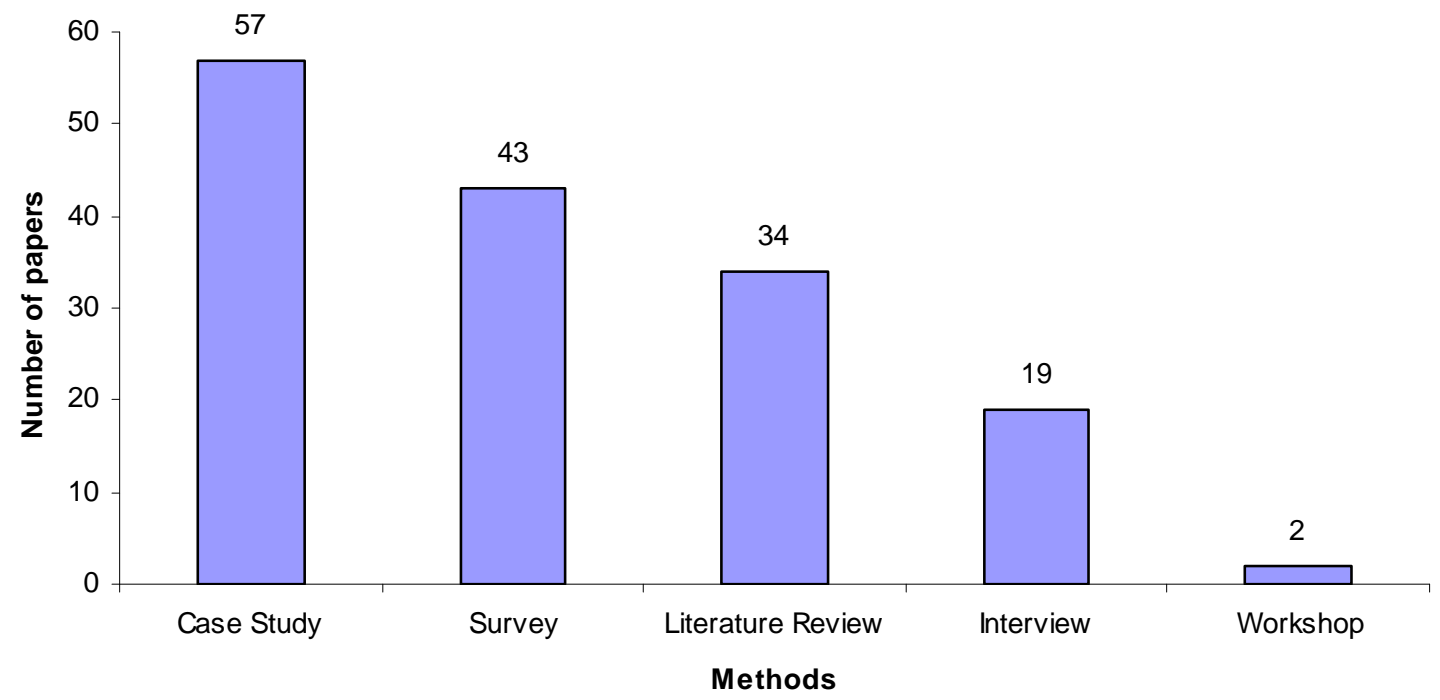

Fig.3. Methods used in selected journal papers.

To set the structure for classifying the studies, some existing classification systems were considered. For example, in a case study by Molenaar and Songer [41], PPP project characteristics were categorized as project, owner, market, and relationship. They further grouped variables that have statistically significant correlations with project success: scope, schedule, budget definition, project complexity, agency experience and staffing, owner design input, design-build market, design-builder prequalification, and method of selection. After having considered these existing systems, the relevant literature was first categorized as "empirical” and "nonempirical” studies. The empirical studies were further classified under the 
headings of "risks", "relationships", and “financing”, while the nonempirical studies were under “financing”, “project success factors”, “risks”, and “concession periods”. The next section describes their contributions in detail. Of the 107 retrieved papers on PPP, 85 studies related to the theoretical model were critically reviewed. Those papers that were not reviewed are given in the bibliography.

\section{Empirical studies of PPP in construction}

Of the 85 reviewed papers, more than half involved a certain degree of empirical work. Empirical studies involve the collection of primary data. These studies have covered a wide range of specific research foci, which can be grouped into three major themes:

- Risks (e.g., Li et al., 2005a; Shen et al., 2006; Akintoye et al., 1998; Li and Tiong, 1999; Li et al., 1999; Schaufelberger and Wipadapisut, 2003; Yeo and Tiong, 2000; Zayed and Chang, 2002; Lam and Chow, 1999; Abednego and Ogunlana, 2006),

- Relationships (e.g., Erridge and Greer, 2002; Ysa, 2007; Zhang and Kumaraswamy, 2001a; Zhang and Kumaraswamy, 2001b; Zhang et al., 2002; Zhang, 2004a; Zhang, 2004b; Abdual-Aziz, 2001; Chan et al., 2003; Consoli, 2006; Palaneeswaran and Kumaraswamy, 2000a; Palaneeswaran and Kumaraswamy, 2000b; Smyth and Edkins, 2007; Wang et al., 1998; Wang et al., 
1999; Wang and Tiong, 1999; Wang et al., 2000a; Wang et al., 2000b; Wang et al., 2000c; Wang and Tiong, 2000; Zhang et al., 1998; Ling, 2004; Zhang, 2005a; Zhang, 2005b; Zhang, 2005c; Ranasingre, 1999; Vazquez and Allen, 2004; Henisz, 2006; El-Gohary et al., 2006), and

- Financing (e.g., Akintoye et al., 2003; Norwood and Mansfield, 1999; Huang and Chou, 2006; Saunders, 1998).

Several empirical studies belong to more than one of the above major themes. For example, key performance determinants of design-bid-build, as one type of PPP, were studied by a survey in Singapore, where the contractor's past record for completing projects on budget and to an acceptable level of quality is expressed as the most significant determinant (Ling, 2004). Clifton and Duffield (2006) also used a survey method to investigate how to improve relationship between the public and private sectors and how to deal with risk management in PPP. Therefore, multi-theme studies will be discussed in individual sections. Studies under these three major themes are presented below.

\subsection{Research into risks}

Research on risks can help to explore the appropriate ways for managing the important risks associated with PPP projects. Risks in PPP can be clustered according to the conventional risk management process: identification of risk areas, risk analysis, 
and risk strategies. To improve the use of risk strategies, risk areas need to be identified and analyzed properly. Research has been carried out to identify the key risk areas and attributes, and to study how clients' contractors and financial institutions perceive risks. For example, previous studies have used questionnaires to collect data for identifying the key risk areas in BOT projects, such as political risks, financial risks, revenue risks, market risks, promoting risks, procurement risks, development risks, construction completion risks, and operating risks (Akintoye et al., 1998; Zayed and Chang, 2002). Schaufelberger and Wipadapisut (2003), through a study of 13 cases, further found that project risks, project conditions, and availability of financing were the major considerations in selecting a financing strategy. The project risks that were argued to be most significant in financing strategy selection were political, financial, and market risks.

Shen et al. (2006), on the other hand, used the case study of Hong Kong Disneyland theme park to analyze the risks affecting project performance. They grouped the important risks into the following 13 categories: site acquisition, unexpected underground conditions, pollution to the land and surroundings, land reclamation, development, design and construction, changes in market conditions, inexperienced private partner, financial, operational, industrial action, legal and policy, and force majeure. Moreover, these risk categories were further divided into three main factor groups: internal, project-specific, and external. On the other hand, there are case studies about the effective risk management measures of international construction joint ventures (e.g., Li and Tiong, 1999; Li et al., 1999; Yeo and Tiong, 
2000). The findings of these studies showed the idea that the most critical risk factors are the financial aspects of joint ventures, government policies, economic conditions, and project relationship.

Apart from risks that were studied in general terms, risks that affected individual project stages were also studied by researchers. For example, the effect of financial risks in BOT projects on different phases of procurement was investigated in a survey (Lam and Chow, 1999). Results suggest that "interest rate fluctuation” was the most significant financial risk in the pre-investment phase, while 'currency exchange restrictions’ was moderately significant in the operational phase.

With respect to practical applications, the above-mentioned key risk areas should be studied carefully and corresponding contingency strategies should be developed when one intends to run a PPP project.

Researchers have also investigated the risk strategies adopted by the public and private sectors. For example, Li et al. (2005a) conducted a questionnaire survey about risk allocation preferences in PPP construction projects in the UK. They found that risks could be distinguished by whether they should be retained by the public sector or shared with the private sector. They further suggested that in PPP construction projects, site availability and political risks should be retained by the public sector partner, while relationship risks, force majeure risks and the risks of legislation changes should be shared by both parties. 


\subsection{Research into relationships}

The relationship between organizations within the public and private sectors is perceived to be crucial to the success of PPP projects because a poor relationship would easily lead to misunderstanding and conflict. Therefore, the existing literature has mainly focused on examining what factors facilitate or inhibit the relationship.

For example, Chan et al. (2003), when conducting an industry-wide survey study, found that 'improved relationship amongst project participants' and 'improved communication amongst project participants' were the most significant benefits obtained from the use of partnering in PPP projects. Through interviews, Consoli (2006) found that various demands of stakeholders, contractual arrangements, and different philosophical standpoints created friction between the involved parties. Apparently, friction is the major course for poor relationships.

Furthermore, researchers have found that sector relationships in PPP projects were determined by the nature of relational contracting and relationship management (e.g., Erridge and Greer, 2002; Ysa, 2007; Smyth and Edkins, 2007). Through a Malaysian case study, Abdul-Aziz (2001) claimed that once privatization has taken place, reinvolvement of the public sector, particularly through the injection of new funds, should be refrained from as much as possible because of its lack of expert experience and possible social impact of the project.

Since a fair deal is what project parties should achieve, researchers have studied the success factors of how to create win-win relations by comparing various kinds of 
BOT-typed infrastructure developments in the United States, the United Kingdom, and China (e.g., Wang et al., 1999; Wang and Tiong, 1999; Wang et al., 2000; Wang et al., 2000a; Wang and Tiong, 2000; Wang et al., 2000b; Zhang et al., 1998; Zhang and Kumaraswamy, 2001b). Their studies were intended to identify the strengths of successful approaches and provide lessons from less successful or abortive projects. In consequence, proper maintenance of relations can be achieved through effective management of political risks, foreign exchange, and revenue risks.

Zhang (2004a; 2004b; 2005a; 2005c) carried out a knowledge-mining process to draw experience and learn lessons from international PPP practices and to refine experiential and expert knowledge underlying the subconscious decision-making process in the field of project financing. He developed five main critical success factors (CSFs) (favorable investment environment, economic viability, reliable concessionaire consortium with strong technical strength, sound financial package, and appropriate risk allocation via reliable contractual arrangements) for a win-win relationship, each of which includes a number of success sub-factors.

Researchers have also related the relationship issue to contractor selection. For choosing suitable contractors, researchers have not only suggested benchmarking the 'best' selection practices, but have also emphasized 'innovative' contractor selection approaches to be used by large public clients, in which relationship is always regarded as a key criterion (e.g., Zhang, 2004a; Zhang, 2004b; Palaneeswaran and Kumaraswamy, 2000a; Palaneeswaran and Kumaraswamy, 2000b). For example, Palaneeswaran and Kumaraswamy (2000a; 2000b) made a comparative overview to 
formulate a ‘cooperative' and 'non-competitive' conceptual benchmarking model to identify the core aspects for selecting a suitable bidder in order to achieve the best 'value for money'.

\subsection{Research into financing}

Having analyzed the data collected from a questionnaire, Norwood and Mansfield (1999) found that financial sources continued to be scarce despite a pressing need for it by contractors. As they argued, some developing countries were gradually more able to provide a higher grade of local technical expertise at competitive prices. This would result in a greater chance for local contractors to compete in overseas markets, and this situation is increasing in Asia. This raises the difficulties for contractors to participate into overseas PPP projects if they are not properly financed. As stated earlier, Schaufelberger and Wipadapisut (2003) found that availability of financing influenced greatly the selection of a favorable financing strategy. Such a strategy can support participation from the private sector.

Akintoye et al. (2003) reviewed the literature and used qualitative analysis to examine factors that could continue to challenge the achievement of best value. They found that among others, high cost of the PFI procurement process is a key factor, which is a burden on the PPP project, and thus leads to a reduction in the private sector willingness to participate. 


\section{Non-empirical studies of PPP in construction}

Non-empirical studies are mainly based on the development of models. Authors have identified four major research directions, which are:

- Financing (e.g., Ho, 2006; Wibowo, 2004; Bakatjan et al., 2003; Ho and Liu, 2002; Chang and Chen, 2001; Subprasom and Chen, 2007; Zhang, 2006a; Zhang, 2006b; Zhang, 2005d; Zhang, 2005e),

- Project success factors (e.g., Kumaraswamy et al., 2007; Salman et al., 2007; Jefferies et al., 2002; Thomas, et al., 2003),

- Risks (e.g., Thomas et al., 2006; Zhang and Zou, 2007; Eaton et al., 2006; Singh and Kalidindi, 2006), and

- Concession periods (e.g., Ng et al., 2007; Ye and Tiong, 2000; Ye and Tiong, 2003; Shen et al., 2002; Shen and Wu, 2005; Shen et al., 2007).

\subsection{Research into financing}

Financing plays an important role in PPPs. Studies that focused on model development addressed different financing issues. Researchers have attempted to study the financial viability of PPP projects. For example, Ho and Liu [76] used an option pricing-based model for evaluating the financial viability of a privatized infrastructure project. To estimate when the project is at risk from bankruptcy, this 
quantitative model takes the views of the project promoter and the government into account. Wibowo (2004) formulated a cash flow model to calculate operating revenues generated by a PPP project. Their research studied guarantees' financial impact from the perspectives of the government and the project sponsor. Simulation results revealed that guarantees could reduce financial viability risk but were not free of cost.

Researchers have also studied the return and the value of PPP projects. For example, Bakatjan et al. (2003) used a simplified model to determine the optimum equity level for decision-makers at the evaluation stage of a BOT project. This model combines a financial model and a linear programming model to maximize the return of the project from the equity holder's point of view. Zhang (2006a; 2006b) argued that there is a need for establishing the best-value objective dimensions for innovative project delivery models. These models could offer the best value to the public sector. The models could also support the partnership between public and private sectors in continuously enhancing the best value through long-term contractual arrangements. Then, a methodology was developed for capital structure optimization and financial viability analysis that reflected the characteristics of project financing, incorporated simulation and financial engineering techniques, and aimed for win-win results for both public and private sectors (Zhang, 2005d; Zhang, 2005e).

Other research, such as rescuing plans and capacity choice, has also been conducted. For example, Ho (2006) developed a game-theory based model, which determines when and how the government would rescue a distressed project and what 
impacts the government's rescue behavior on project procurement and management. By establishing an effective rescue model, the government would be able to map out the blueprint for the public, develop policies, and negotiate with the concessionaire (Chang and Chan, 2001). Subprasom and Chen (2007) provided modeling and analysis of highway pricing and capacity choice of a BOT scheme. It was found that the combination of toll charge and roadway capacity regulation performed the best in terms of social welfare increment. Yet, in PPP highway projects, the regulation may cause a financial pressure against the private investors to operate a project. The government, therefore, may need to subsidize the private investors in order to make their participation financially viable.

\subsection{Research on project success factors}

Researchers have studied what influence the success of PPP projects. For example, Kumaraswamy et al. (2007) developed a force field model to visualize the importance of relational forces. A framework was conceptualized to link the relational contracting approaches, through sustainable relationships, to sustainable infrastructure. Salman et al. (2007) introduced a decomposed evaluation model to assess the most commonly significant decision factors that strongly affected the feasibility of BOT projects. 


\subsection{Research into risks}

Risks are always an active research topic for PPP projects. Thomas et al. (2006) proposed a risk probability and impact assessment framework based on fuzzy-fault tree and the Delphi method. The framework included extensive scenario modeling of critical risks in projects and systematic processing of professional judgement of experts.

Zhang and Zou (2007), on the other hand, developed a fuzzy analytical hierarchy process model for the appraisal of the risk environment pertaining to the joint venture projects. Eaton et al. (2006) developed a theoretical model for the construction industry, which specifies the potential stimulants and impediments to creative behavior in PPP projects.

\subsection{Research into concession periods}

Capital investment of the private partner is recovered through the operational revenue over the concession period. Research has been conducted on how to determine the length of the concession period. For example, Ng et al. (2007) proposed a simulation model to assist the public partner to determine an optimal concession period. The simulation output showed that risks and uncertainties, such as a change in inflation rate, traffic flow, and operation cost, could influence the decision on the concession period. Through Monte Carlo simulation, Ye and Tiong (2000; 2003) 
provided a method for evaluating the mean net present value (NPV), variance, and NPV-at-risk of different concession period structures. Risk-return trade-off was studied to make sure a sufficiently long concession period for generating financial returns that can compensate the risks.

Other studies have been focused on developing a model for determining the concession period for BOT projects (e.g., Shen et al., 2002; Shen and Wu, 2005). The model was used to identify a specific concession period, which took into account the bargaining behavior of the two parties engaged into a BOT contract (Shen et al., 2007).

\section{Future studies}

The paper has so far presented a system that classified empirical and nonempirical studies. The review of these studies has provided insights for designing future research agendas. The following discussion thus recommends some possible research plans.

\subsection{Risks}

Previous studies have attempted to identify the risks in PPP by using a small sample or a small number of cases. To make the risk identification results more meaningful, the use of a larger sample size is recommended. Such a larger sample 
should include practicing professionals (Shen et al., 2007). Moreover, future research should also be focused on exploring more convincing risk assessment models. As noted by Medda (2007) and Xenidis and Angelides (2005), it is crucial to create risk assessment models to incorporate different types of risks (such as technical and legal risks). Such models should not only be accurate, but should also be easier to be used. Models that are resisted by practitioners would be of no use to the real world.

\subsection{Financing}

Existing studies have shown that too much and too little governmental guarantee or support can not achieve a suitable balance. Especially when the government provides too much guarantee, it would be easy for the concessionaire to get the benefit from the contract at the expense of the public. This has led to the commonly asked question of how to pursue a win-win scenario between the public sector, the private sector, and ultimate general public users (e.g. Zhang, 2005a; Zhang, 2005b). Future research should therefore be designed to find such an answer.

Since prior research has highlighted the importance of collaborative arrangements in public procurement that transfers from a 'controlling regime' to a 'facilitative stage', the conditions that would help to speed up the transfer process need to be identified. This is consistent with Erridge and Greer's (2002) contention that the social capital underscoring the productive bonding between parties and the role of government in facilitating positive outcomes resulting from the social capital should 
be developed. Furthermore, the cultural and political issues in PPP should also be addressed under new agendas. PPP experiences cannot be simply copied from one country to another since different countries have different practices in terms of culture and policy. Research should be undertaken to address the relationship issue by evaluating the effect of cultural mismatch and other relational variables on project team success (e.g. Sillars and Kangari, 2004).

\subsection{Contractual agreements}

Like Wang et al. (1999), the current paper recommends the improvement of contractual agreements. In fact, partners in a project should make sure that the contractual language is effective and that the contractual clauses conform to international practices. However, conflict and argument about contractual terms are not uncommon. One of the possible areas for improvement is the provision of clear definitions of financial indicators for foreign sponsors and lenders to avoid unnecessary misunderstanding.

Since negative behavioral relations and tendencies may lead to adversarial or litigious relations in contract implementation, more research would be needed to explore which factors affect behaviors. For example, contract terms may be a key factor as they are perceived to generally have greater impact upon relationship performance (Edkins and Smyth, 2006). 


\subsection{Development of PPP models}

Appropriate political, legal, and economic environments are essential to PPPs. For PPP projects to work smoothly, the impact level of these environmental issues should be identified, especially when relating to different PPP types (e.g. Kumaraswamy and Zhang, 2001; Zhang and Kumaraswamy, 2001). Both empirical and operational studies are useful to establish PPP decision models. Empirically, conceptual models can be developed based on case studies, and can be tested by use of a representative sample. Moreover, an appropriate decision-making technique should be employed to set up a decision model for estimating the specific impact level of the environmental issues on a particular PPP project.

\subsection{Concession periods}

As the concession period is important for generating returns for the private partner, future concession models should not only take the government's interests but also those of the private investor into consideration. Usually, simulation models can be used to identify the most appropriate concession periods. In addition to qualitative variables, quantitative variables should be incorporated in order to propose a more robust model for simulation testing (Ng et al., 2007). 
6.6 Strategies in choosing the right type of PPP

In individual situations, different types of PPP need be carefully selected to adapt to real situations.

Since the failure rate of joint ventures has been high, partners are recommended to monitor both the internal and external conditions in the host country. By knowing the key factors, joint ventures can be enacted and sustained properly. Among others, internal factors include partner fit, partner relations, and structural characteristics, while external factors include host country conditions and project risks. As suggested by Ozorhon et al. (2007a, 2007b), both of the direct and indirect effects should be evaluated simultaneously.

Previous research has indicated that non-privately funded PPP approaches were more cost-effective in the delivery of maintenance services when compared to the traditional term contract (Devapriya, 2006; Ng and Wong, 2006). However, for practicing the 'big market, small government' policy in Hong Kong, privately funded PPP approaches are expected to dominate the market. Thus, research should be conducted to determine whether privately funded PPP projects are also more costeffective. If not, research needs to be undertaken to explore how to improve them. 


\section{Conclusions}

The review undertaken in this paper covers popular research topics in the PPP area. In empirical studies, three specific characteristics of PPP - risks, relationships, and financing - have been mainly studied. Research has been carried out on identifying risk categories, analyzing risk factors and formulating risk strategies. Factors affecting relationships between the public sector and the private sector have also been identified based on win-win situations. Financial sources and the way to achieve best value for money are important for the private sector. In nonempirical studies, research has been conducted on such aspects as financing, project success, risks, and concession periods. Models and simulation methods have been used to value factors for success in these four aspects. Moreover, insights have been provided to offer further research directions for PPP in construction. By conducting extra research, more effective ways can be developed to manage the relationship between the public sector and the private sector. In the past decade or so, great changes have happened in the construction industry because of PPP practices, especially to urban development and city building. It is expected that changes will continue to evolve in the future when more research has been undertaken and new findings have been reported. 


\section{Acknowledgement}

The research was supported by a grant from the Hong Kong Polytechnic University, the Hong Kong Special Administrative Region, China.

\section{References}

Abdul-Aziz, A.R. (2001). “Unraveling of BOT scheme: Malaysia’s Indah water konsortium.” Journal of Construction Engineering and Management, 127(6), 457460.

Abednego, M.P. and Ogunlana, S.O. (2006). “Good project governance for proper risk allocation in public-private partnerships in Indonesia.” International Journal of Project Management, 24(7), 622-634.

Akintoye, A., Beck, M., and Hardcastle, C. (2003a). "Introduction: public-private partnership in infrastructure development.” PBLIC-PRIVATE PARTNERSHIPS: Managing risks and opportunities, A. Akintoye, M. Beck and C. Hardcastle, Blackwell Science Ltd., xix-xxiv.

Akintoye, A., Jardcastle, C., Beck, M., Chinyio, E., and Asenova, D. (2003b). "Achieving best value in private finance initiative project procurement." Construction Management and Economics, 21(5), 461-470. 
Akintoye, A., Taylor, C., and Fitzgerald, E. (1998). "Risk analysis and management of private finance initiative projects.” Engineering, Construction and Architectural Management, 5(1), 9-21.

Algarni, A.M., Arditi, D., and Polat, G. (2007). "Build-operate-transfer in infrastructure projects in the United States.” Journal of Construction Engineering and Management, 133(10), 728-735.

Al-Sharif, F. and Kaka, A. (2004). "PFI/PPP Topic Coverage in Construction Journals.” ARCOM 20 th annual conference, Heriot Watt University, Blackwell, 711-719.

Bakatjan, S., Arikan, M., and Tiong, R.L.K. (2003). “Optimal capital structure model for BOT power projects in Turkey." Journal of Construction Engineering and Management, 129(1), 89-97.

Ball, M. and Maginn, P.J. (2005). “Urban change and conflict: evaluating the role of partnerships in urban regeneration in the UK.” Housing Studies, 20(1), 9-28.

Chan, A.P.C., Chan, D.W.M., and Ho, K.S.K. (2003). “An empirical study of the benefits of construction partnering in Hong Kong.” Construction Management and Economics, 21(5), 523-533.

Chang, L.M. and Chen, P.H. (2001). “BOT financial model: Taiwan high speed rail case.” Journal of Construction Engineering and Management, 127(3), 214-222.

Chau, K.W. (1997). "The ranking of construction management journals." Construction Management and Economics, 15(4), 387-398. 
Clifton, C. and Duffield, C.F. (2006). “Improved PFI/PPP service outcomes through the integration of Alliance principles.” International Journal of Project Management, 24(7), 573-586.

Consoli, G.G.S. (2006). "Conflict and managing consortia in private prison projects in Australia-Private prison operator responses.” International Journal of Project Management, 24(1), 75-82.

Cumming, D. (2007). “Government policy towards entrepreneurial finance: Innovation investment funds.” Journal of Business Venturing, 22(2), 193-235.

Devapriya, K.A.K. (2006). “Governance issues in financing of public-private partnership organizations in network infrastructure industries.” International Journal of Project Management, 24(7), 557-565.

Eaton, D., Akbiyikli, R., and Dickinson, M. (2006). “An evaluation of the stimulants and impediments to innovation within PFI/PPP projects.” Construction Innovation, 6(2), 63-77.

Edkins, A.J. and Smyth, H.J. (2006.) “Contractual management in PPP projects: evaluation of legal versus relational contracting for service delivery.” Journal of Professional Issues in Engineering Education and Practice, 132(1), 82-93.

Efficiency Unit. (2005a). “About Private Sector Involvement.” < http://www.eu.gov.hk/english/psi/psi_psi/psi_psi_over/psi_psi_over.html> (Apr. 16, 2008). 
Efficiency Unit. (2005b). "Vision and mission statements." <http://www.eu.gov.hk/english/about/about_vm/about_vm.html> (April 16, 2008).

El-Gohary, N.M., Osman, H. and El-Diraby, T.E. (2006). "Stakeholder management for public private partnerships.” International Journal of Project Management, 24(7), 595-604.

Erridge, A. and Greer, J. (2002). "Partnerships and public procurement: building social capital through supply relations.” Public Administration, 80(3), 503-522.

Grimsey, D. and Lewis, M.K. (2002). "Evaluating the risks of public private partnerships for infrastructure projects.” International Journal of Project Management, 20(2), 107-118.

Hart, O. (2003). “Incomplete contracts and public ownership: remarks, and an application to public-private partnerships.” The Economic Journal, 113(486), c69c76.

Henisz, W.J. (2006). “Governance issues in public private partnerships.” International Journal of Project Management, 24(7), 537-538.

Ho, S.P. (2006). “Model for financial renegotiation in public-private partnership projects and its policy implications: game theoretic view." Journal of Construction Engineering and Management, 132(7), 678-688.

Ho, S.P. and Liu, L.Y. (2002). “An option pricing-based model for evaluating the financial viability of privatized infrastructure projects.” Construction Management and Economics, 20(2), 143-156. 
Huang, Y.L. and Chou, S.P. "Valuation of the minimum revenue guarantee and the option to abandon in BOT infrastructure projects.” Construction Management and Economics, 24(4), 379-389.

James, A.D., Cox, D., and Rigby, J. (2005). “Testing the boundaries of public private partnership: the privatization of the UK Defense Evaluation and Research Agency.” Science and Public Policy, 32(2), 155-161.

Jefferies, M., Gameson, R. and Rowlinson, S. (2002). "Critical success factors of the BOOT procurement system: reflections from the Stadium Australia case study.” Engineering Construction and Architectural Management, 9(4), 352-361.

Kumaraswamy, M.M., Ling, F.Y.Y., Anvuur, A.M., and Rahman, M.M. (2007). “Targeting relationally integrated teams for sustainable PPPs.” Engineering, Construction and Architectural Management, 14(6), 581-596.

Kumaraswamy, M.M. and Morris, D.A. (2002). "Build-operate-transfer type procurement in Asian megaprojects." Journal of Construction Engineering and Management, 128(2), 93-102.

Kumaraswamy, M.M. and Zhang, X.Q. (2001). "Governmental role in BOT-led infrastructure development.” International Journal of Project Management, 19(4), 195-205.

Lam, K.C. and Chow, W.S. (1999). "The significance of financial risks in BOT procurement.” Building Research \& Information, 27(2), 84-95. 
Li, B. and Akintoye, A. (2003). “An overview of public-private partnership.” PBLICPRIVATE PARTNERSHIPS: Managing risks and opportunities, A. Akintoye, M. Beck and C. Hardcastle, Blackwell Science Ltd., UK, 3-30.

Li, B., Akintoye, A., Edwards, P.J., and Hardcastle, C. (2005a). "The allocation of risk in PPP/PFI construction projects in the UK.” International Journal of Project Management, 23(1), 25-35.

Li, B., Akintoye, A., Edwards, P.J., and Hardcastle, C. (2005b). “Critical success factors for PPP/PFI projects in the UK construction industry.” Construction Management and Economics, 23(5), 459-471.

Li, B. and Tiong, R.L.K. (1999). "Risk management model for international construction joint ventures.” Journal of Construction Engineering and Management, 125(5), 377-384.

Li, B., Tiong, R.L.K., Fan, W.W., and Chew, D.A.S. (1999). "Risk management in international construction joint ventures.” Journal of Construction Engineering and Management, 125(4), 277-284.

Li, H., Cheng, E.W.L., and Love, P.E.D. (2000). "Partnering research in construction.” Engineering, Construction and Architectural Management, 7(1), 76-92.

Ling, Y.Y. (2004). “Key determinants of performance of design-bid-build projects in Singapore.” Building Research \& Information, 32(2), 128-139.

Luo, J., Gale, A., and He, X.X. (2001). "Investing in the Chinese construction industry via joint ventures.” Building Research \& Information, 29(4), 277-285. 
Medda, F. (2007). “A game theory approach for the allocation of risks in transport public private partnerships.” International Journal of Project Management, 25(3), 213-218.

Molenaar, K.R. and Songer, A.D. (1998). "Model for public sector design-build project selection.” Journal of Construction Engineering and Management, 124(6), 467-479.

Ng, B. (2000). "Privatisation of ethnic wealth redistribution in Malaysia: experiences and lessons for developing countries.” Public and Private Sector Partnerships: the enabling Mix, L. Montanheiro \& M.Linehan, eds., Sheffield Hallam University, Sheffield, 461-467.

Ng, S.T. and Wong, Y.M.W. (2006). “Adopting non-privately funded public-private partnerships in maintenance projects - a case study in Hong Kong. Engineering,” Construction and Architectural Management, 13(2), 186-200.

Ng, S.T., Xie, J.Z., Cheung, Y.K., and Jefferies, M. (2007). “A simulation model for optimizing the concession period of public-private partnerships schemes.” International Journal of Project Management, 25(8), 791-798.

Norwood, S.R. and Mansfield, N.R. (1999). “Joint venture issues concerning European and Asian construction markets of the 1990's.” International Journal of Project Management, 17(2), 89-93.

Ozorhon, B., Arditi, D., Dikmen, I., and Birgonul, M.T. (2007a). "Effect of host country and project conditions in international construction joint ventures.” International Journal of Project Management, 25(8) 799-806. 
Ozorhon, B., Dikmen, I., and Birgonul, M.T. (2007b). "Using analytic network process to predict the performance of international construction joint ventures.” Journal of Management in Engineering, 23(3), 156-163.

Palaneeswaran, E. and Kumaraswamy, M.M. (2000a). "Benchmarking contractor selection practices in public-sector construction-a proposed model.” Engineering, Construction and Architectural Management, 7(3), 285-299.

Palaneeswaran, E. and Kumaraswamy, M.M. (2000b). "Contractor selection for Design/Build projects.” Journal of Construction Engineering and Management, 126(5), 331-339.

Ranasingre, M. (1999). "Private sector participation in infrastructure projects: a methodology to analyze viability of BOT." Construction Management and Economics, 17(5), 613-623.

Sagalyn, L.B. (2007). "Public/private development: lessons from history, research, and practice.” Journal of the American Planning Association, 73(1), 7-22.

Salman, A.F.M., Skibniewski, M.J., and Basha, I. (2007). "BOT viability model for large-scale infrastructure projects.” Journal of Construction Engineering and Management, 133(1), 50-63.

Saunders, A. (1998). “Aspects of funding for BOO projects.” Engineering Construction and Architectural Management, 5(1), 22-30.

Schaufelberger, J.E. and Wipadapisut, I. (2003). “Alternate financing strategies for Build-Operate-Transfer projects.” Journal of Construction Engineering and Management, 129(2), 205-213. 
Shen, L.Y., Bao, H.J., Wu, Y.Z., and Lu, W.S. (2007). "Using bargaining-game theory for negotiating concession period for BOT-type contract.” Journal of Construction Engineering and Management, 133(5), 385-392.

Shen, L.Y., Li, H., and Li, Q.M. (2002). "Alternative concession model for build operate transfer contract projects.” Journal of Construction Engineering and Management, 128(4), 326-330.

Shen, L.Y., Platten, A., and Deng, X.P. (2006). "Role of public private partnerships to manage risks in public sector projects in Hong Kong.” International journal of Project Management, 24(7), 587-594.

Shen, L.Y. and Wu, Y.Z. (2005). "Risk concession model for build/operate/transfer contract projects.” Journal of Construction Engineering and Management, 131(2), 211-220.

Sindane, J. (2000). "Public-private partnerships: case study of solid waste management in Khayelitsha-Cape Town, South Africa.” Public and Private Sector Partnerships: the enabling Mix, L. Montanheiro \& M.Linehan, eds., Sheffield Hallam University, Sheffield, 539-564.

Sillars, D.N. and Kangari, R. (2004). "Predicting organizational success within a project-based joint venture alliance.” Journal of Construction Engineering and Management, 130(4), 500-508.

Singh, L.B. and Kalidindi, S.N. (2006). "Traffic revenue risk management through annuity model of PPP road projects in India.” International Journal of Project Management, 24(7), 605-613. 
Smyth, H. and Edkins, A. (2007). "Relationship management in the management of PFI/PPP projects in the UK.” International Journal of Project Management, 25(3), 232-240.

Subprasom, K. and Chen, A. (2007). "Effects of regulation on highway pricing and capacity choice of a Build-Operate-Transfer scheme.” Journal of Construction Engineering and Management, 133(1), 64-71.

Tanninen-Ahonen, T. (2000). "PPP in Finland: developments and attitude.” CIB W92 Procurement System Symposium, A. Serpell, eds., Santiago, Chile, 631-639.

The Canadian Council for Public Private Partnerships. (2004). “About PPP.” <http://www.pppcouncil.ca/aboutPPP_definition.asp> (May 15, 2007).

The World Bank and the International Finance Corporation (IFC). (1992). "Investing in the environment.” The World Bank, Washington, DC.

Thomas, A.V., Kalidindi, S.N. and Ananthanarayanan, K. (2003). “Risk perception analysis of BOT road project participants in India.” Construction Management and Economics, 21(4), 393-407.

Thomas, A.V., Kalidindi, S.N., and Ganesh, L.S. (2006). “Modelling and assessment of critical risks in BOT road projects.” Construction Management and Economics, 24(4), 407-424.

Tranfield, D., Rowe, A., Smart, P.K., Levene, R., Deasley, P., and Corley, J. (2005). "Coordinating for service delivery in public-private partnership and private finance initiative construction projects: early finding from an exploratory study.” 
Proceedings of The Institution of Mechanical Engineers PART B - Journal of Engineering Manufacture, 219, 165-175.

United Nations Development Programme (UNDP). (2005). "What are public-private partnerships.” <http://pppue.undp.org/> (June 16, 2007).

Vazquez, F. and Allen, S. (2004). "Private sector participation in the delivery of highway infrastructure in Central America and Mexico." Construction Management and Economics, 22(7), 745-754.

Wang, S.Q. and Tiong, R.L.K. (1999). "Political risks: analysis of key contract clauses in China's BOT project.” Journal of Construction Engineering and Management, 125(3), 190-197.

Wang, S.Q. and Tiong, R.L.K. (2000). “Case study of government initiatives for PRC’s BOT power plant project.” International Journal of Project Management, 18(1), 69-78.

Wang, S.Q., Tiong, R.L.K., Tong, S.K., and Ashley, D. (1999). "Political risks: analysis of key contract clauses in China's BOT project.” Journal of Construction Engineering and Management, 125(3), 190-197.

Wang, S.Q., Tiong, R.L.K., Tong, S.K., and Ashley, D. (2000a). "Evaluation and management of foreign exchange and revenue risks in China's BOT projects.” Construction Management and Economics, 18(2), 197-207.

Wang, S.Q., Tiong, R.L.K., Tong, S.K., and Ashley, D. (2000b). “Foreign exchange and revenue risks: analysis of key contract clauses in China's BOT project.” Construction Management and Economics, 18(3), 311-320. 
Wang, S.Q., Tiong, R.L.K., Tong, S.K., and Ashley, D. (2000c). "Evaluation and management of political risks in China's BOT projects.” Journal of Construction Engineering and Management, 126(3), 242-250.

Wang, S.Q., Tiong, R.L.K., Tong, S.K., Chew, D. and Ashley, D. (1998). "Evaluation and competitive tendering of BOT power plant project in China.” Journal of Construction Engineering and Management, 124(4), 333-341.

Wibowo, A. (2004). "Valuing guarantees in a BOT infrastructure project." Engineering, Construction and Architectural Management, 11(6), 395-403.

Winch, G.M. (2000). "Institutional reform in British construction: partnering and private finance.” Building Research \& Information, 28(2), 141-155.

Xenidis, Y. and Angelides, D. (2005). “The financial risks in build-operate-transfer projects.” Construction Management and Economics, 23(4), 431-441.

Ye, S. and Tiong, R.K.L. (2000). “Government support and risk-return trade-off in China's BOT power projects.” Engineering, Construction and Architectural Management, 7(4), 412-422.

Ye, S. and Tiong, R.K.L. (2003). "The effect of concession period design on completion risk management of BOT projects.” Construction Management and Economics, 21(5), 471-482.

Yeo, K.T. and Tiong, R.L.K. (2000). "Positive management of differences for risk reduction in BOT projects.” International Journal of Project Management, 18(4), 257-265. 
Ysa, T. (2007). "Governance forms in urban public-private partnerships.” International Public Management Journal, 10(1), 35-57.

Zayed, T.M. and Chang, L.M. (2002). "Prototype model for Build-Operate-Transfer risk assessment.” Journal of Management in Engineering, 18(1), 7-16.

Zhang, G.M., Zou, P.X.W. (2007). "Fuzzy analytical hierarchy process risk assessment approach for joint venture construction projects in China.” Journal of Construction Engineering and Management, 133(10), 771-779.

Zhang, W.R., Wang, S.Q., Tiong, R.L.K., Tong, S.K., and Ashley, D. (1998). "Risk management of Shanghai's privately financed Yan'an Donglu tunnels.” Engineering, Construction and Architectural Management, 5(4), 399-409.

Zhang, X.Q. (2004a). “Concessionaire selection: methods and criteria.” Journal of Construction Engineering and Management, 130(2), 235-244.

Zhang, X.Q. (2004b). “Improving concessionaire selection protocols in public/private partnered infrastructure projects.” Journal of Construction Engineering and Management, 130(5), 670-679.

Zhang, X.Q. (2005a). “Critical success factors for Public-Private Partnerships in infrastructure development." Journal of Construction Engineering and Management, 131(1), 3-14.

Zhang, X.Q. (2005b). "Paving the way for public-private partnerships in infrastructure development.” Journal of Construction Engineering and Management, 131(1), 7180. 
Zhang, X.Q. (2005c). “Criteria for selecting the private-sector partner in PublicPrivate Partnerships.” Journal of Construction Engineering and Management, 131(6), 631-644.

Zhang, X.Q. (2005d). “Financial viability analysis and capital structure optimization in privatized public infrastructure projects.” Journal of Construction Engineering and Management, 131(6), 656-668.

Zhang, X.Q. (2005e). “Concessionaire’s financial capability in developing BuildOperate-Transfer type infrastructure projects.” Journal of Construction Engineering and Management, 131(10), 1054-1064.

Zhang, X.Q. (2006a). "Public clients' best value perspectives of Public Private Partnerships in infrastructure development.” Journal of Construction Engineering and Management, 132(2), 107-114.

Zhang, X.Q. (2006b). "Factor analysis of public clients' best-value objective in public-privately partnered infrastructure projects.” Journal of Construction Engineering and Management, 132(9), 956-965.

Zhang, X.Q. and Kumaraswamy, M.M. (2001a). “Hong Kong experience in managing BOT projects.” Journal of Construction Engineering and Management, 127(2), 154-162.

Zhang, X.Q. and Kumaraswamy, M.M. (2001b). “Procurement protocols for publicprivate partnered project.” Journal of Construction Engineering and Management, 127(5), 351-358. 
Zhang, X.Q., Kumaraswamy, M.M., Zheng, W., and Palaneeswaran, E. (2002). “Concessionaire selection for Build-Operate-Transfer tunnel projects in Hong Kong.” Journal of Construction Engineering and Management, 128(2), 155-163.

\section{Bibliography}

Ahadzi, M. and Bowles, G. (2004). "Public-private partnerships and contract negotiations: an empirical study." Construction Management and Economics, 22(9), 967-978.

Akintoye, A. and Chinyio, E. (2005). "Private finance initiative in the healthcare sector: trends and risk assessment.” Engineering Construction and Architectural Management, 12(6), 601-616.

Bossink, B.A.G. (2002). “A Dutch public-private strategy for innovation in sustainable construction.” Construction Management and Economics, 20(7), 633642.

Carrillo, P.M., Robinson, H.S., Anumba, C.J. and Bouchlaghem, N.M. (2006). “A knowledge transfer framework: the PFI context." Construction Management and Economics, 24(10), 1045-1056.

Chan, W.T., Chen, C., Messner, J.I. and Chua, D.K.H. (2005). “Interface management for China’s build-operate-transfer projects.” Journal of Construction Engineering and Management, 131(6), 645-655. 
Chen, C. and Messner, J. (2005). “An investigation of Chinese BOT projects in water supply: a comparative perspective.” Construction Management and Economics, 23(9), 913-925.

Chen, M.S., Lu, H.F. and Lin, H.W. (2006). “Are the nonprofit organizations suitable to engage in BOT or BLT scheme? A feasible analysis for the relationship of private and nonprofit sectors.” International Journal of Project Management, 24(3), 244-252.

Cheng, L.Y. and Tiong, R.L.K. (2005). "Minimum feasible tariff model for BOT water supply projects in Malaysia.” Construction Management and Economics, 23(3), 255-263.

Fischer, K., Jungbecker, A. and Alfen, H.W. (2006). “The emergence of PPP task forces and their influence on project delivery in Germany.” International Journal of Project Management, 24(7), 539-547.

Henk, G.G. (1998). "Privatization and the public/private partnership.” Journal of Management in Engineering, 14(1), 28-29.

Holmes, J., Capper, G., and Hudson, G. (2006). "Public private partnerships in the provision of health care premises in the UK." International Journal of Project Management, 24(7), 566-572.

Jefferies, M. (2006). “Critical success factors of public private sector partnerships.” Engineering Construction and Architectural Management, 13(5), 451-462. 
Kleiss, T. and Imura, H. (2006). "The Japanese private finance initiative and its application in the municipal solid waste management sector.” International Journal of Project Management, 24(7), 614-621.

Koch, C. and Buser, M. (2006). "Emerging metagovernance as an institutional framework for public private partnership networks in Denmark.” International Journal of Project Management, 24(7), 548-556.

Leiringer, R. (2006). “Technological innovation in PPPs: incentives, opportunities and actions.” Construction Management and Economics, 24(3), 301-308.

Li, B., Akintoye, A., Edwards, P.J. and Hardcastle, C. (2005). "Perceptions of positive and negative factors influencing the attractiveness of PPP/PFI procurement for construction projects in the UK: Findings from a questionnaire survey.” Engineering Construction and Architectural Management, 12(2), 125-148.

Munns, A.K., Aloquili, O. and Ramsay, B. (2000). “Joint venture negotiation and managerial practices in the new countries of the former Soviet Union.” International Journal of Project Management, 18(6), 403-413.

Ng, S.T. and Wong, Y.M.W. (2007). "Payment and audit mechanisms for non privatefunded PPP-based infrastructure maintenance projects.” Construction Management and Economics, 25(9), 915-924.

Smith, N., Zhang, H. and Zhu, Y.R. (2004). “The Huaibei power plant and its implications for the Chinese BOT market." International Journal of Project Management, 22(5), 407-413. 
Tam, C.M. (1999). “Build-operate-transfer model for infrastructure developments in Asia: reasons for successes and failures." International Journal of Project Management, 17(6), 377-382.

Tse, R.Y.C. and Love, P.E.D. (2001). "Property rights implications of public-private joint ventures: a comment.” Construction Management and Economics, 19(7), 663-668.

Wong, K.C. and Walker, A. (2000). "Property rights implications of public-private joint ventures.” Construction Management and Economics, 18(2), 131-138.

Zantke, G. and Mangels, B. (1999). "Public sector client-private sector project: transferring the state construction administration into private hands.” Engineering Construction and Architectural Management, 6(1), 78-87. 